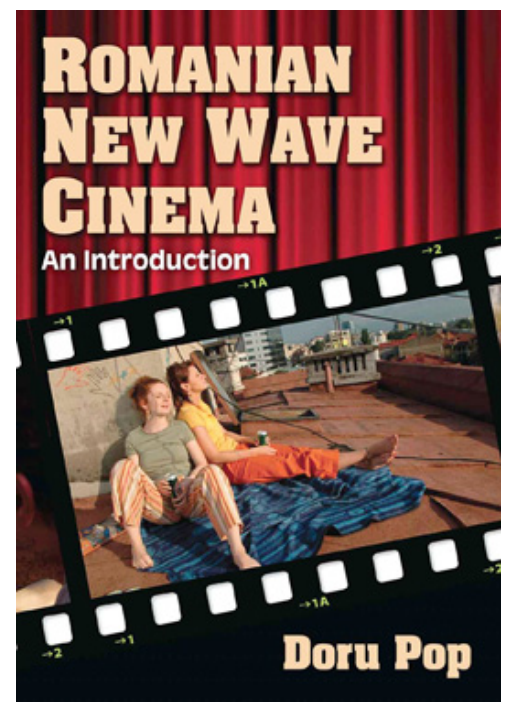

Romanialainen nykyelokuva herätti 2000-luvulla laajaa kiinnostusta, kun realistisia, maan sosiaalista todellisuutta ja inhimillisiä tarinoita vähäeleisesti kuvaavia elokuvia juhlittiin elokuvafestivaaleilla vuosikymmenien hiljaisuuden jälkeen. New York Times, Washington Post ja The Guardian kirjoittivat "Romanian uudesta aallosta", ja vaihtoehtoelokuvan nuoret ohjaajalahjakkuudet, kuten Cristi Puiu, Corneliu Porumboiu ja Cristian Mungiu, tulivat tutuiksi kansainväliselle elokuvayleisölle. Alkuinnostus on jo laantunut ja jäänyt muun muassa georgialaisen elokuvan viime vuosina herättämän mielenkiinnon varjoon. Silti esimerkiksi syksyn Rakkautta ja anarkiaa -festivaalilla Mungiun Cannesissa parhaasta ohjauksesta palkittu Valmistujaiset (Bacalaureat, 2016) toi Savoy-teatteriin täyden salillisen yleisöä.

Cluj Napocan Babeș-Bolyai yliopiston Elokuva- ja mediatutkimuksen laitoksella työskentelevän Doru Popin tutkimus Romanian New Wave Cinema: An Introduction (2014) hahmottaa Romanian uuden aallon elokuvan (Noul val românesc) estetiikkaa ja visuaalista kielioppia. Kiistelty nimitys viittaa Nicolae Ceaușescun kommunistisen totalitarismin aikana kasvaneen ja vallankumoksen eläneen uuden ohjaajasukupolven elokuviin. Maahan kehittyi 2000-luvun kuluessa laaja riippumattoman elokuvan kenttä, jonka edustajia palkittiin lukuisasti kansainvälisillä elokuvafestivaaleilla.

Popin tutkimuksen tavoitteena on osoittaa Romanian uusi aalto omaksi genrekseen esteettisin kriteerein. Tyylillisesti se eroaa hänen mu- kaansa sekä kaupallisesta amerikkalaisesta että vallankumouksen jälkeisen Romanian muusta elokuvatuotannosta ja asettuu aiempien uuden aallon elokuvasuuntausten jatkumoon. Kansallisen elokuvakoulun sijaan Romanian uusi aalto on Popin mukaan osa eurooppalaisen vaihtoehtoelokuvan perinnettä.

Kirjoittajan vuosiin 2001-2011 ajoittaman uuden aallon estetiikka nousee realistisen $\mathrm{ku}-$ vaustavan elämänmakuisuudesta, kerronnan tämänhetkisyydestä, inhimillisestä lähestymistavasta eettisiin ja yhteiskunnallisiin ongelmiin sekä katsojan osallistamisesta elokuvan todellisuuteen. Pop etsii ilmaisun erityisyyttä pelkistetyn elokuvakerronnan, näyttämöllepanon ja kuvaustekniikan synnyttämästä dokumentaarisuuden ja autenttisuuden vaikutelmasta. Pitkät, todellisissa kaupunkimiljöissä kuvatut otokset, cinéma vérité -henkinen kuvaustekniikka sekä vähäinen lavastus, valaistus ja editointi rakentavat suorapuheista elokuvakerrontaa, jossa yksilön draama tarjoaa puitteet eettisten kysymysten tarkastelulle.

Esteettisten keinojen rinnalla elokuvia yhdistävät Popin mukaan toistuvat teemat: marginaaliset henkilöhahmot, muuttoliike, ongelmallinen isä-poika-suhde, sukupuoli ja romanialaiselle kulttuurille ominainen musta huumori, joista kutakin käsitellään kirjassa omassa analyysiluvussaan. Maan lähihistoriaa ja sen vaikutuksia yksilöön kuvaava ohjaajapolvi jakaa kirjoittajan mukaan myös yhteiskuntakriittisen otteen, vallan rakenteita kriittisesti tarkastelevan auktoriteetin vastaisen asenteen. 
Kirjan teoreettiset lähestymistavat kurottavat elokuvantutkimuksesta psykoanalyysiin, ikonologiaan ja semiotiikkaan, joita täydentävät viittaukset filosofiaan, taidehistoriaan, feministiseen teoriaan ja teatterintutkimukseen. Tulkinnallisesta kehyksestä toiseen poukkoileva ote tekee tarkastelutavasta ajoittain pinnallisen mutta nostaa toisaalta elokuvista esille olennaisia piirteitä. Antoisimmillaan Popin tutkimus on runsaslukuisissa analyyttisissa huomioissa, jotka avaavat elokuvien sisällöllisiä ja esteettisiä ratkaisuja suhteessa romanialaiseen nyky-yhteiskuntaan ja kommunistisen diktatuurin menneisyyteen. Käsittelyluvuissa elokuvien teemat ja tyylipiirteet osoitetaankin useimmiten juuri vastalauseiksi "punaisen Hollywoodin" ideologisesti värittyneelle propagandalle, jota tiukka sensuurikoneisto Romaniassakin hallitsi.

Kommunistisen yhteiskunnan pyrkimyksiä tukeneen sosialistisen realismin illuusioiden sekä ideaalisen ja voittoisan "uuden ihmisen" tilalle nousivat huonoja moraalisia valintoja tekevät, passiiviset antisankarit, ironisoiden vailla todellista valtaa kuvatut vallanpitäjät tai kommunistisen vallan autoritäärisyyden ja kumouksellisen nuoren sukupolven ristiriitoihin vertautuvat kompleksiset isä-poika-suhteet. Kirjoittajan korostamat yhtymäkohdat 1900-luvun puolivälin auteur-elokuvaan ja uuden aallon realistiseen ilmaisuun selittyvät samoin vastarinnan ilmaisuina. Kommunistisella ajalla elokuvaohjaaja oli työläinen muiden joukossa ja kokeellinen elokuvailmaisu mahdoton askel kohti länttä ja sen ilmaisunvapautta.

Romaniassa elokuva-ala on säilynyt ilmeisen miehisenä. Kirjan kiinnostavimpia onkin sukupuolen ja seksuaalisuuden representaatiota käsittelevä luku. Se paikkaa tältä osin olennaisella tavalla aiempaa englanninkielistä julkaisua, Brysselin Université Libren romanialaissyntyisen elokuvatutkimuksen professorin Dominique Nastan monografiaa Contemporary Romanian Cinema: The History of an Unexpected Miracle (2013), jossa sekä naiset ohjaajina että sukupuolen kriittinen tarkastelu jäävät hämmentävän ohueksi. Romanian New Wave Cinema esittelee nykyelokuvan tekijöistä muun muassa Ruxanda Zeniden, Adina Pintilien, Anca Damianin ja Iona Uricarun, mutta myös "vanhan kaartin" ohjaajanaisia, kuten Elisabeta Bostanin ja Malvina Urşianun.
Popin mukaan kommunistisen ajan elokuvissa Romanian patriarkaalisen yhteiskunnan sovinismi yhdistyi patrioottiseen sovinismiin. Näennäisestä sukupuolten tasa-arvosta huolimatta elokuvissa kansallista historiaa rakensivat miehiset työläissankarit, isähahmot ja vallanpitäjät. Naisten osaksi jäivät niin elokuvassa kuin yhteiskunnassakin vähäpätöisemmät sivuroolit sekä stereotyyppiset naiskuvat, kuten hoivaavat, suojelevat äitihahmot, yksinäiset lesket, neitsyet ja huorat. Vaikka feministisestä tai naiselokuvasta ei Romaniassa Popin mukaan edelleenkään voi puhua, kirjoittivat jo uuden aallon elokuvaohjaajat uusiksi patriarkaalisia narratiiveja ja kuvasivat todenmukaisemmin naisten todellisuutta. Etäiset, lapsensa hylkäävät äidit, ongelmaiset, hajoavat perheet, rakkaus samaan sukupuoleen sekä naisten haavoittuva asema yhteiskunnassa tulivat osaksi romanialaisen nykyelokuvan kuvastoja. Feminismin sijaan tekijöiden motivaationa lienee kuitenkin ollut pikemmin kommunistiseen menneisyyteen kohdistuva kritiikki.

Popin tutkimus selittää myös realistisen ilmaisun politiikan etäisyydenotoksi "vanhan koulun" elokuvan keinotekoisiin todellisuuksiin ja propagandistisiin (piilo)merkityksiin. Romanian uusi aalto tutkimuskohteena alleviivaakin myös realismin pyrkimysten moninaisuutta ja ajallisia ja maantieteellistä kerrostumia elokuvan tyylisuuntana. Romanialaisen kriitikko Alex Leo Şerbanin jalanjäljissä Pop etsii Romanian uuden aallon elokuvien vaikutteita ennen kaikkea 1900-luvun puolivälin eurooppalaisista uusista aalloista, italialaisesta neorealismista ja Ranskan La Nouvelle Vaguen bazinilaisista pyrkimyksistä ja jäljittää niiden yhteisiä juuria edelleen Vertovin kino-pravdaan.

Samalla kirja nostaa esille neuvostorealismin estetiikan monisyisyyden 1900-luvun alkuvuosikymmenien kokeellisesta neuvostoelokuvasta harhaan johtavaan propagandaan saakka. Realismi haastoi "kapitalistisen elokuvan" fiktiivisyyden mutta kasvoi myös avantgarde-elokuvan kanssa jaetusta tavoitteesta lisätä taiteen roolia yhteiskunnallisessa muutoksessa. 2000-luvun uuden aallon edelläkävijäksi ja romanialaisen elokuvailmaisun radikaaliksi uudistajaksi Pop nostaa Cristi Puiun, jonka todellisuutta sellaisenaan tapaileva esitystapa ohjasi maan riippumattoman elokuvan etäälle myös 1990-luvun elokuvan 
vulgaarista, kyynisestä ja brutaaleja shokkikeinoja käyttävästä "miserabilismista". Puiun ohjaamista elokuvista versoi kokonaiselle ohjaajasukupolvelle ominainen realistinen tyyli, joka kertoo arjen tragikoomisia tarinoita toteavasti - havainnoiden, tuomitsematta ja vailla eksplisiittisen poliittisia kantoja.

Yhdessä Nastan laajemmalle yleisölle suunnatun kirjan kanssa Romanian New Wave Cinema antaa monipuolisen yleiskuvan suhteellisen vähäisesti tunnetun romanialaisen elokuvan vuodesta 1911 alkavasta historiasta. 1960-luvulle tultaessa Romaniaan oli kehkeytynyt vilkas elokuvatuotanto, joka ei Ceaușescun totalitaristisen hallinnon aikana (1967-1989) levinnyt Sergiu Nicolaescun Veristä valloittajaa
(1970) lukuun ottamatta maan ulkopuolelle. Nastan selventäessä elokuvien historiallista ja sosio-poliittista kontekstia, keskittyy Popin tutkimus elokuvailmaisun yksityiskohtaiseen analyysiin ja antaa käsityksen myös uuden aallon elokuvasta Romaniassa käydystä keskustelusta. Kirja tarjoaa lähtökohdan Romanian nykyelokuvan kansainväliselle tutkimukselle, joka oletettavasti lähdeaineiston romaniankielisyydestä ja saavutettavuudesta johtuen on vielä silmiinpistävän vähäistä.

\section{Riikka Niemelä}

FM, Taidehistoria, Turun yliopisto 